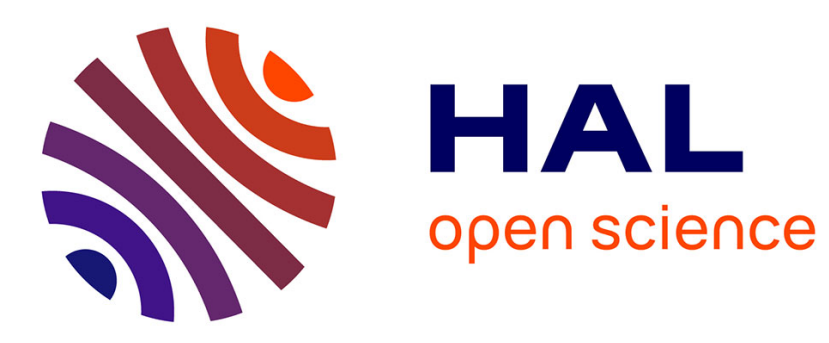

\title{
Levels of nitrate in Swedish lettuce and spinach over the past ten years
}

Leonardo Merino, Per Ola Darnerud, Ulla Edberg, Per Åman, Maria del Pilar

Castillo

\section{- To cite this version:}

Leonardo Merino, Per Ola Darnerud, Ulla Edberg, Per Åman, Maria del Pilar Castillo. Levels of nitrate in Swedish lettuce and spinach over the past ten years. Food Additives and Contaminants, 2006, 23 (12), pp.1283-1289. 10.1080/02652030600930543 . hal-00577282

\section{HAL Id: hal-00577282 \\ https://hal.science/hal-00577282}

Submitted on 17 Mar 2011

HAL is a multi-disciplinary open access archive for the deposit and dissemination of scientific research documents, whether they are published or not. The documents may come from teaching and research institutions in France or abroad, or from public or private research centers.
L'archive ouverte pluridisciplinaire $\mathbf{H A L}$, est destinée au dépôt et à la diffusion de documents scientifiques de niveau recherche, publiés ou non, émanant des établissements d'enseignement et de recherche français ou étrangers, des laboratoires publics ou privés. 


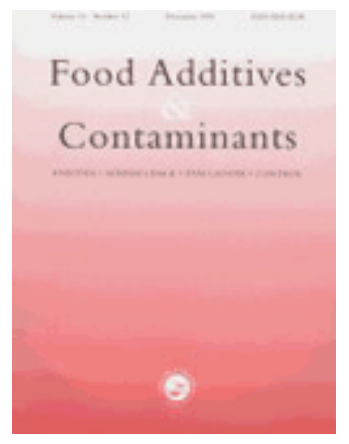

\section{Levels of nitrate in Swedish lettuce and spinach over the past ten years}

\begin{tabular}{|r|l|}
\hline Journal: & Food Additives and Contaminants \\
\hline Manuscript ID: & TFAC-2006-058.R1 \\
\hline Manuscript Type: & Review \\
\hline Author: & 07-Jul-2006 \\
\hline Complete List of Authors: & $\begin{array}{l}\text { Merino, Leonardo; Swedish National Food Administration, Research } \\
\text { \& Development } \\
\text { Darnerud, Per Ola; Swedish National Food Administration, Research } \\
\text { \& Development } \\
\text { Edberg, Ulla; Swedish National Food Administration, Research \& } \\
\text { Development } \\
\text { Aman, Per; Swedish University of Agricultural Sciences, Food } \\
\text { Science } \\
\text { Castillo, Maria del Pilar; Swedish University of Agricultural Sciences, } \\
\text { Microbiology }\end{array}$ \\
\hline Methods/Techniques: & Chromatography - HPLC \\
\hline Additives/Contaminants: & Nitrate \\
\hline Food Types: & Vegetables \\
\hline & \\
\hline
\end{tabular}

\section{SCHOLARONE \\ Manuscripts}




\title{
Levels of nitrate in Swedish lettuce and spinach over the past ten years
}

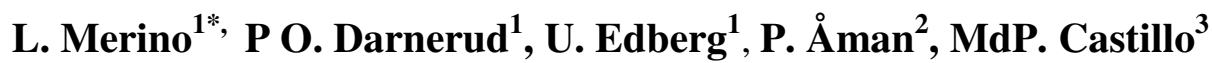 \\ ${ }^{1}$ National Food Administration, Chemistry Division 2, \\ Box 622 \\ SE-75126 Uppsala \\ Sweden, \\ ${ }^{2}$ Swedish University of Agriculture Sciences, \\ Department of Food Science \\ Box 7051 \\ SE-750 07 Uppsala, \\ Sweden \\ ${ }^{3}$ Swedish University of Agriculture Sciences, \\ Department of Microbiology \\ Box 7025 \\ SE-750 07 Uppsala, \\ Sweden
}

*Corresponding author :- Leonardo Merino leme@slv.se

\begin{abstract}
Monitoring of nitrate in Swedish-produced lettuce and spinach over the past ten years (19962005) showed that more than $95 \%$ of the samples were below the maximum levels established by the European Commission in 1997. The good agricultural practices used by Swedish farmers may partly explain these results. Analytical results of organic farming production of lettuce from year 2000 showed low nitrate levels compared to conventional production. The ten years of Swedish experience has shown good compliance with the EU maximum levels, but even lower nitrate levels may be achieved by organic farming methods, at least regarding fresh lettuce grown under cover.
\end{abstract}




\section{Introduction}

Our intake of nitrate is from three main sources: vegetables, drinking water and food additives. Among them vegetables are generally the major source $(75 \%-91 \%)$, yet in some areas drinking water can account for the major contribution (European Commission Scientific Committee for Food 1997). Nitrate is a natural component of vegetables originating from the uptake of nitrate ions in excess of its reduction and subsequent assimilation. The concentration of nitrate in vegetables depends on genetic factors, environmental variables and agricultural practice (Maynard et al. 1976).

When vegetables are classified according to their capacity of nitrate accumulation, genetic factors are most pronounced and commonly mask the effects of the other factors. In 1995 the National Food Administration (NFA), based on a survey of nitrate levels in vegetables from the Swedish retails market, made the following categorization: high levels $(>1000 \mathrm{mg} / \mathrm{kg})$ - fresh lettuce, spinach, intermediate levels (350-1000 mg/kg)- Chinese cabbage, iceberg lettuce, leek, beetroot, white cabbage, and low levels $(<350 \mathrm{mg} / \mathrm{kg})$ - broccoli, cucumbers, carrot, cauliflower, potato, tomato (Merino et al. 1997). Thus, lettuce and spinach are those with relatively high nitrate accumulation capacity.

The environmental factors affecting nitrate levels in vegetables are light, temperature, humidity, $\mathrm{CO}_{2}$-atmosphere, water supply, etc. It is well documented that low light intensity is often associated with increased nitrate concentration in plants (Cantliffe 1972). Hence, nitrate levels tend to be higher in samples from northern Europe than those from Mediterranean countries. The nitrate content in vegetables grown under cover is usually considerable higher than in those grown in the open air in the same seasons (European Commission SCF 1997). In general, 
environmental variables may exert a marked effect on nitrate accumulation, but they are difficult to handle (Maynard et al. 1976).

\begin{abstract}
With the use of Good Agricultural Practices (GAP) it may be easier to control the levels of nitrate in vegetables and much work is focussed on this topic. Light, plant density, watering, fertilizing, sprinkling, etc. are some of the variables considered in GAP (EC DG VI/4857/97, EC DG VI/8108/97, EC DG VI/8421/97, EC DG VI/8437/97).
\end{abstract}

The scientific discussion about the potential risk with the usage of nitrate in the agricultural and food sector is focussed on two major topics, namely environmental and health aspects. In the 1970s there was an intense nitrate debate due to the potential relationship between the use of nitrates and nitrites as additives and the formation of carcinogenic nitrosamines. Nitrate - and its derivate nitrite - is also associated to a disease affecting the oxygen transport in blood (methaemoglobinaemia), of which babies are most susceptible (Walker 1990). Hence, the Scientific Committee for Food (SCF) based on toxicological studies of the increase in circulating methaemoglobin (using a safety factor of 500) established an Acceptable Daily Intake (ADI) for nitrate of $3.7 \mathrm{mg} / \mathrm{kg}$ body weight (European Commission SCF 1997).

The intake of nitrate and nitrite from food are generally well within the ADIs. Thus, studies performed in the UK showed that taking into account nitrate intake from the rest of the diet, even the highest nitrate levels found in the UK Monitoring Programme are not likely to cause even high-level consumers of lettuce or of spinach to exceed the ADI (Food Surveillance Information sheet, 2003). An estimation of Swedish intake showed a mean intake of $18-21 \mathrm{mg} / \mathrm{day}$ and a $95 \%$ percentile intake of 63-72 mg/day (Fernlöf and Darnerud 1996), to be compared with the ADI of $222 \mathrm{mg} /$ day. However, there may be a considerable range in nitrate intake levels depending on 
other sources than vegetables, and the presence of nitrate-contaminated drinking water could drastically increase the total intake. We know that small children are especially sensitive to the effects of methaemoglobinemia, and that infant formula made with water with high nitrate levels could be a serious health risk. To eliminate potential risks, the Swedish NFA also recommends that small children should not be given juices made of nitrate-rich vegetables, such as beetroot.

To conclude, consumers seem in general to be sufficiently protected, as regards health effects, by the present regulation. High nitrate intake levels, which could be harmful especially in small children, may primarily be the result of factors other than nitrate in vegetables, e.g. contaminated drinking water. From a risk-benefit viewpoint, the beneficial health effects of vegetable consumption must also be taken into account. Moreover, a recently published study stresses evidence of the beneficial effects of some derivatives of nitrate e.g. nitric oxides to help regulate blood pressure and protect the stomach against harmful substances (gastric juice, strong spices, alcohol, bacteria, etc) (Lundberg et al. 2004).

As indicated above, the concern for the environmental and health aspects of nitrate as a water pollutant is still of great interest. The EU monitoring networks indicate that over $20 \%$ of groundwater and between 30 and $40 \%$ of lakes and rivers show excessive nitrate concentration and agricultural sources account for between 50 and $80 \%$ of the nitrate entering Europe's water (European Commission 2005). Nutrients emissions from agriculture are the main reason for eutrophication. Rivers are now discharging several hundred thousands tonnes of nitrogen a year into the Baltic Sea. Swedish watercourses, however, account for only a minor proportion of this input. Instead the greater part comes from Eastern Europe, where population and agricultural acreage are considerably greater. In Sweden, about 100000 people today are dependent on drinking water, which contains nitrate concentrations in excess of the limit (10 mg $\left.\mathrm{NO}_{3}-\mathrm{N} / \mathrm{litre}\right)$ 
(Swedish EPA, 2005). Hence it is important to control the pollution caused by nitrates from agricultural sources, to which codes of GAP play a key role (Council Directive 91/676/EEC).

The evaluation of the results of a Monitoring Programme for nitrate in lettuce and spinach, together with the adopted GAP codes and an updated scientific risk assessment will be used by the European Commission to establish a longer-term strategy for managing the risk from nitrate in vegetables. This includes the review of the maximum levels lay down in 1997 (European Commission 2001).

In 1995 the Swedish NFA evaluated the content of nitrates in vegetables (Merino et al. 1997), and in 1996 started a monitoring programme for nitrate in lettuce and spinach cultivated in Sweden. The result of this study is presented in this paper.

\section{Materials and methods}

Chemicals

All reagents must be of analytical grade and the water used of at least grade 1 as defined in the standard ISO 3696:1987

\section{Equipment}

Liquid chromatograph, isocratic system equipped with UV detector. Analytical separating column, anion exchanger, $4.6 \mathrm{~mm}$ x $150 \mathrm{~mm}$, packing material (e.g. Waters IC Pak HC); polymethacrylate resin with a quaternary ammonium functional group, particle size of $10 \mu \mathrm{m}$.

\section{Samples}

The samples studied were fresh lettuce, iceberg lettuce, fresh and frozen spinach. 


\section{Sample collection}

The samples collected during the Monitoring Programme followed the European Commission guidelines (European Commission DG VI/1655/97), i.e. one sample per two metric ton of production with a minimum of 12 samples per year for product. Fresh lettuces, iceberg lettuce together with fresh and frozen spinach representative of the seasonal growing and the geographical areas of the country were collected annually by the Swedish NFA. Each collected laboratory sample consisted of at least 10 individual vegetables. The samples were homogenised as a whole and frozen to $-18^{\circ} \mathrm{C}$ until analysis.

In the summer of year 2000 a project was started by the NFA to compare organic, conventional and integration farming in relation to the quality of the food produced. The project considered the analysis of content of bacteria, vitamins, metals, pesticides, nitrate, etc. (Staffas 2002). From a total of 100 samples, $24 \%$ of the fresh and iceberg lettuces came from organic farming. These results are included for comparison and are not a part of the Monitoring Programme.

\section{Sample preparation}

Nitrate was extracted from the sample with hot water $\left(50-60^{\circ} \mathrm{C}\right)$ and the test solution treated with acetonitrile to remove suspended material (NMKL No. 165 2000).

\section{Analytical Method}

The ion was determined by ion chromatography with ultraviolet detection at $205 \mathrm{~nm}$ (NMKL No.165 2000). 


\section{Quality control}

The method accomplishes the criteria for analytical performance established by the European Commission (EC DG VI/4800/96-Rev-1). Our laboratory has previously evaluated this method. Thus, extraction, clean-up and chromatographic conditions were some of the parameters studied. Furthermore, an internal validation and two collaborative studies with the participation of 15 European laboratories were performed (Merino et al. 2000). The recovery calculated in the single validation was $103 \%$. The recovery factor was not statistically significant; therefore it was not used to correct the results. The uncertainty calculated in a single validation study was lower than the uncertainty obtained from an interlaboratory study (Fig. 1). Because the confidence of the statistical parameters from interlaboratory studies is higher than the single validation (Codex Alimentarius Commission 2005), the former was used to interpret the results.

[Insert Fig 1 about here]

Throughout the Monitoring Programme, the Swedish NFA laboratory followed the recommended internal quality control procedure and participated annually in proficiency testing schemes with satisfactory performances.

\section{Results and discussion}

The yearly nitrate levels in lettuce and spinach are shown in Figures 2 and 3, respectively. The summary of the nitrate content, expressed as median, is presented in Table I. No significant differences were observed between the median and mean values in any of the studied vegetable 
groups, indicating a fairly normal distribution of the sample values. Some differences in levels were observed during the 10-year observation time, but no clear-cut time trend was obvious.

\begin{abstract}
A total of 159 samples of fresh lettuce were analysed. These samples were cultivated under cover during winter and summer. The median value found was of $2684 \mathrm{mg} \mathrm{NO} / \mathrm{kg}$, which is below the maximum limits established by the European Commission. However, four samples exceeded the regulatory limits, two were summer samples from 1996 and 1998 and two winter samples from year 2000 (Table I, Fig. 2). The producers were informed for corrective actions.
\end{abstract}

The median of the iceberg lettuce $931 \mathrm{mg} \mathrm{NO}_{3} / \mathrm{kg}$ was well below the regulatory limit (Table I, Fig. 3). However, in the year 1996 one high value was observed. All the Swedish production of iceberg lettuce is produced on uncovered fields during the summer season.

\title{
[Insert Fig 2, 3, about here] \\ [Table I about here]
}

The results from organic farming showed that the median nitrate levels in fresh lettuce was 826 $\mathrm{mg} \mathrm{NO} / \mathrm{kg}$ and that in iceberg lettuce $672 \mathrm{mg} \mathrm{NO} / \mathrm{kg}$. Although only comparing nitrate data from one year (2000), the results indicate that organic farming, at least when compared to conventional farming of vegetables with fairly high nitrate levels (i.e. fresh lettuce), could lead to a substantial decrease in these levels. However, this is not the case with iceberg lettuce where it seems that the genetic factor is more important and masks the influence of the environmental factors and agricultural practices. In the study from 2000 fresh lettuce from organic production (826 mg NO $3 / \mathrm{kg} ; \mathrm{n}=14$ ) could be compared both with those from integrated production (1708 mg $\mathrm{NO}_{3} / \mathrm{kg} ; \mathrm{n}=28$ ) and from conventional production (2484 mg NO$/ \mathrm{kg} ; \mathrm{n}=5$ ) (Staffas 2000), which may give further evidence for the importance of the production manner for the nitrate levels. 
There are other studies showing that organic farming in average has the potential of reducing nitrate levels in vegetables products (Brand et al. 2001). However, the literature also reports studies showing inconsistent or not significant difference in nitrate content in conventional and organically grown crops. (Lyons DJ, et.al, 1994; Woese K. et.al 1997)

A total of 63 samples of fresh spinach were analysed with a median concentration of $1747 \mathrm{mg}$ $\mathrm{NO}_{3} / \mathrm{kg}$ (Table I, Fig 4). Twelve samples from year 1996 exceeded the maximum level specified in the regulation. All those samples came from the same producer who was using the vegetables for further processing as frozen spinach and not for direct consumption in the market.

The results of 70 frozen spinach samples with a median concentration of $551 \mathrm{mg} \mathrm{NO} / \mathrm{kg}(\mathrm{Table}$ I, Fig 5), confirm that, as it is well known, the nitrate content in processed vegetables is usually much less than in fresh vegetables due to the loss of nitrate during the blanching process (Maynard et al. 1976).

[Insert Fig 4, 5, about here]

In theory the adverse climatic conditions in Sweden, with low light intensity, may promote high levels of nitrates in plants. However, concentrations below the maximum levels of nitrate were observed in $96 \%$ of the samples analysed during 10 years of the Monitoring Programme. The good agriculture practices, which in Sweden could be performed as Integrated Production (IP) (Green Production 2005) or organic farming, controlled by KRAV or Demeter (http:/www.krav.se), allows the Swedish farmers to produce lettuce and spinach fulfilling the European regulations. The Swedish IP criteria are revised every two years and contain instructions that specifically address how to reduce nitrate levels in lettuce. Today, about half 
(lettuce under cover) or $75 \%$ (iceberg lettuce) of the production area for commercial lettuce production belongs to growers connected to the Swedish organisation for IP production.

The adopted quality criteria for the analytical methods and sampling to be used by monitoring laboratories should minimise the adverse influence of these factors in the variability of the data. Consequently, the comparison of the levels of nitrate between Member States will be easier. Also a better insight of the role of agricultural practice on the nitrate levels in vegetables is gained.

There is a potential public health risk with elevated nitrate levels in food because of possible nitrosamine formation, as well as methaemoglobin. On the other hand, in the light of increasing evidence that the reduction of nitrate to nitrite and the subsequent formation of biologically active nitrogen oxides could be beneficial, the previous view emphasising only the harmful effects of the intake of high nitrate may be reconsidered (Lundberg et al. 2004). However, although, these new studies are discovering interesting aspects of the biological chemistry of the nitrogen cycle, they do not deny yet that the pollution of the environment with nitrate is a major public health problem (European Commission SCF 1997).

\section{Conclusions}

Former surveys made by the NFA in Sweden in 1985 and 1995 (Lönberg et al. 1985; Merino et al. 1997) and the results of the monitoring programme reported in this paper show a sustained low concentration of nitrate in lettuce and spinach cultivated in Sweden. During the last 5 years no samples with nitrate levels over the maximum limits established by the European Commission have been found. The specific instruction regarding nitrate reduction in lettuce production introduced by Swedish producer organisations may be an important factor in explaining these results. 
Lower nitrate levels in organic farming were found in fresh lettuce but not in iceberg lettuce. This could indicate that the suitability of the agricultural practice as a regulator of the utilization of nitrogen could be limited by genetic factors. The monitoring programme is an effective tool to map out the nitrate levels in lettuce and spinach and its continuation would allow final conclusions about the role played by the GAP in the decrease of the nitrate content. The ten years of Swedish experience strengthen the opinion that there is no technical reason to increase the European maximum level established in 1997.

\section{Acknowledgements}

This project was supported by the Swedish National Food Administration.

\section{References}

Brand K, Molgaard P. 2001. Organic agriculture: does it enhance or reduce the nutritional value of plant foods? Journal of Science of Food Agriculture 81:924-931.

Cantliffe D. 1972. Nitrate accumulation in vegetables crops as affected by photoperiod and light duration. Journal of the American Society for Horticultural Science 97(3): 414-418.

Green Production 2005. Available from: http://www.gronproduktion.se. Accessed 2006 Feb 9

Codex Alimentarius Commission 2005. Draft Guidelines for evaluating acceptable methods of analysis. WHO/FAO.

Council Directive 91/676/EEC of 12 December 1991 concerning the protection of waters against pollution caused by nitrates from agricultural sources.

European Commission 2005. Pollution caused by nitrates from agricultural sources. Available from: http://europa.eu.int/scadplus/scad_en.htm 
European Commission DG VI/4857/97. GAP spinach and lettuce-Finland.

European Commission DG VI/8108/97. GAP protected lettuce-Ireland

European Commission DG VI/8437/97. GAP spinach and lettuce-UK

European Commission DG VI/8421/97. GAP butterhead lettuce

European Commission DG VI/1655/97. Monitoring Programme Nitrates: Number of samples.

European Commission DG VI/4800/96-Rev-1. Guidelines for laboratories carrying out the determination of nitrate in lettuce and spinach: EC Monitoring Programme.

European Commission: Scientific Committee for Food 1997. Opinions of the Scientific Committee for Foods on nitrates and nitrite, Luxembourg.

European Commission 2001. European Commission Regulation 466/2001/EC, of 8 March 2001, setting maximum levels for certain contaminants in foodstuffs. Available at: http://europa.eu.int/eur-lex/en/consleg/pdf/2001/en_2001R0466_do_001.pdf. Accessed 2005 Dec 19.

Fernlöf G, Darnerud PO. 1996. N-nitroso compounds and precursors in food-level, intake and health effect data and evaluation of risk. SLV-Rapport 15. Available from: http:/www.slv.se

Food Surveillance Information sheet 2004. UK Monitoring programme for nitrate in lettuce and spinach 2000-2002. Available from: http://foodf/gov.uk/food_surv.htm

Krav (internet). Available from: http:/www.krav.se

Lyons DJ, Rayment GE, Nobbs PE, McCallum LE. 1994. Nitrate and nitrite in fresh vegetables from Queensland. Food Additives and Contaminants 64:279-281

Lönberg E, Everitt G. 1985. Nitrat i grönsaker. Vår Föda 37:316-322. Available from: http:/www.slv.se

Lundberg JO, Weitzberg E, Jeff A, Benjamin CN. 2004. Nitrate, bacteria and human health. Nature Reviews Microbiology. 2, 593-602. 
Maynard DN, Barker AV, Minotti PL, Peck NH. 1976. Nitrate accumulation in vegetables. In: Advances in Agronomy, American Society of Agronomy. Vol. 28. Academic Press, New York.

Merino L, Sandberg E, Danerud PO. 1997. Låga nitrathalter i svenska grönsaker. Vår Föda 7: 2428. Available from: http:/www.slv.se

Merino L, Edberg U, Fuchs G, Åman P. 2000. Liquid chromatographic determination of residual nitrite/nitrate in foods: NMKL collaborative study. Journal of the Association of Official Analytical Chemists. 83, No. 2, 365-375.

Nordic Committee on Food Analysis 2000. Nitrite and nitrate in foodstuffs by ion chromatography. NMKL No. 165. Available from: http:/www.nmkl.org

Staffas A, Grönhholm R. 2002. Sallat \& Vitaminer. Vår Föda 1:28-29. Available from: http:/www.slv.se

Swedish EPA, 2005. Eutrophication of soil and water. Available from: http://www.internat.naturvardsverket.se. Accessed 2005 Dec 19

Walker R. 1990. Nitrates and N-nitroso compounds: a review of the occurrence in food and diet and the toxicological implications. Food Additives and Contaminants 7:717-768.

Woese K, Lange D, Boess Ch, Bögl KW. 1997. A comparison of organically and conventionally grown foods-results of a review of the relevant literature. Food Additives and Contaminants 74:281-293 
Table I. Incidence of nitrate above maximum level (ML) detected through Monitoring Programme 1996-2005

\begin{tabular}{lcccc}
\hline \multicolumn{1}{c}{ Type } & No. samples & $\begin{array}{c}\text { Median } \\
\left(\mathrm{mg} \mathrm{NO}_{3} / \mathrm{kg}\right)\end{array}$ & $\begin{array}{c}\text { Range } \\
\left(\mathrm{mg} \mathrm{NO}_{3} / \mathrm{kg}\right)\end{array}$ & $\begin{array}{c}\text { No. above } \\
\text { ML }\end{array}$ \\
\hline Fresh lettuce & 159 & 2684 & $58-5406$ & 4 \\
Iceberg lettuce & 71 & 931 & $94-2298$ & 1 \\
Fresh spinach & 63 & 1747 & $47-5975$ & 12 \\
Frozen spinach & 70 & 551 & $213-1862$ & 0 \\
Fresh lettuce (organic farming)* & 14 & 826 & $442-2038$ & 0 \\
\hline
\end{tabular}

* Samples not included in the Monitoring Programme 


\section{Figures legends}

Figure 1. Estimation of uncertainty using the step-by-step method and its comparison with the uncertainty calculated from data of an interlaboratory study. The single validation combined uncertainty $\left(\mu_{\mathrm{c}}=4.69\right)$ includes the overall precision $\left(\mu_{\mathrm{R}}=4.40\right)$ and the bias uncertainty $\left(\mu_{\operatorname{Rec}}=\right.$ 1.65). The uncertainties of calibration, weighing and volume are included in the overall precision. The interlaboratory uncertainty $(\mu=5.59)$ was used to interpret the results of the Monitoring Programme.

Figure 2. Nitrate content of fresh lettuce during years 1995-2005. Four samples exceeded the maximum levels (ML), one in summer 1996, one in summer 1998 and two in winter 2000 (ML summer $=3500 \mathrm{mg} / \mathrm{kg}, \mathrm{ML}$ winter $=4500 \mathrm{mg} / \mathrm{kg}$ ).

Figure 3. Nitrate content in iceberg lettuce during years 1995-2005. One value in the year 1996 exceeded the maximum level. Due to few samples taken, the results of the years 1997-1999 are merged.

Figure 4. Nitrate content in open air fresh spinach during years 1996-2005. Twelve samples exceeded the ML in 1996-1997 and one sample in 2000-2001. During 1998-1999 only two samples of fresh spinach were analysed. (ML summer $=2500 \mathrm{mg} / \mathrm{kg}$ ).

Figure 5. Nitrate content in frozen spinach during years 1996-2005. All samples were below the maximum level $(\mathrm{ML}=2000 \mathrm{mg} / \mathrm{kg})$. 
Fig. 1

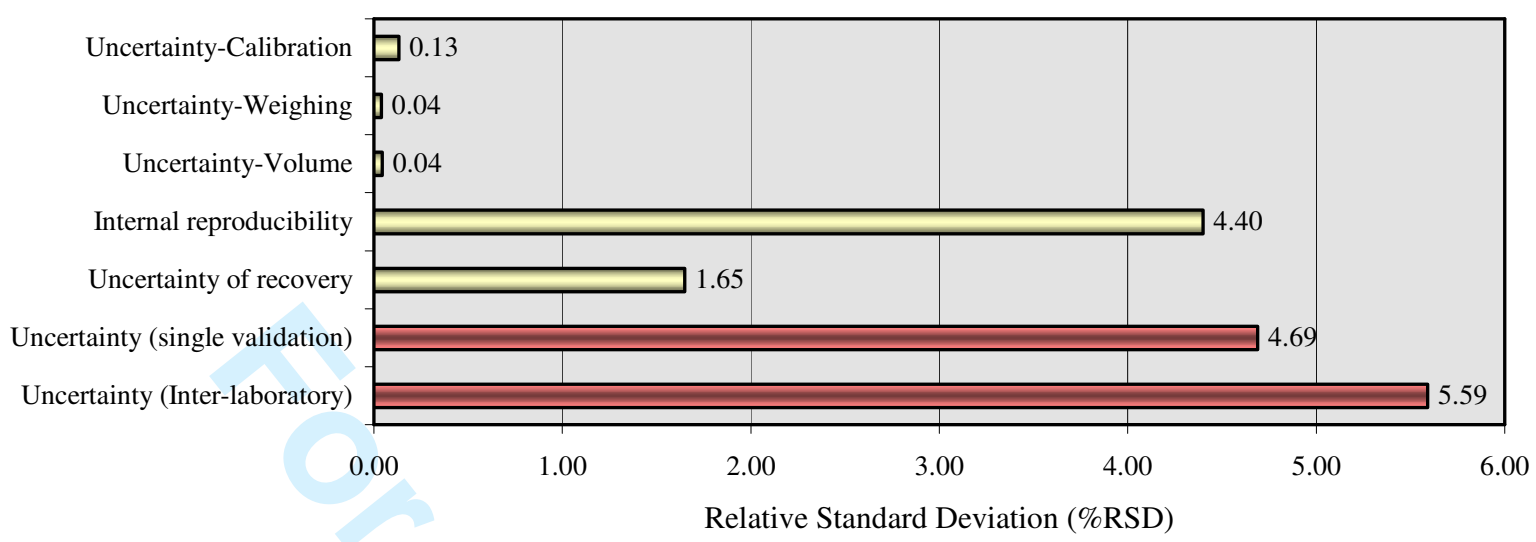




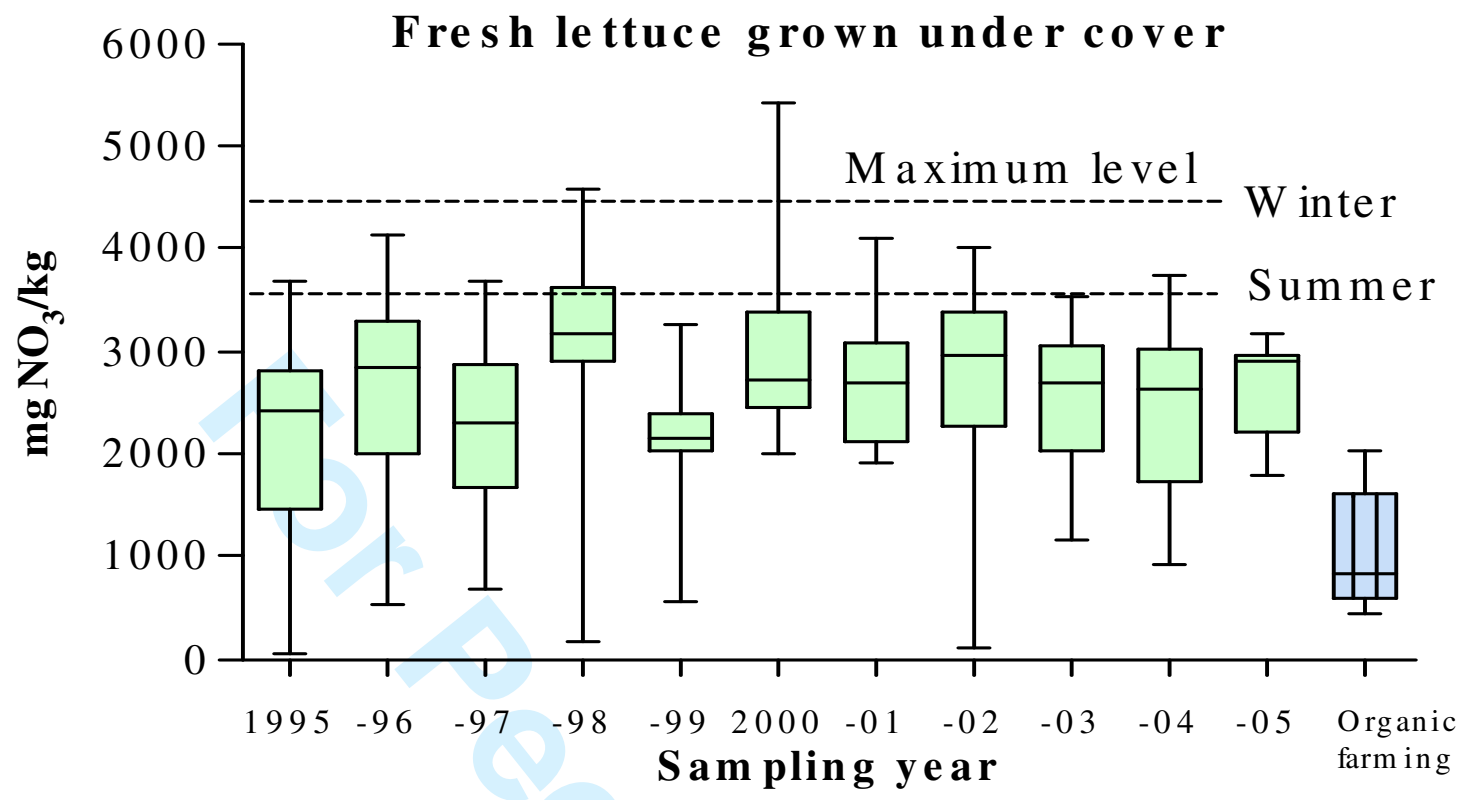

Fig. 2 


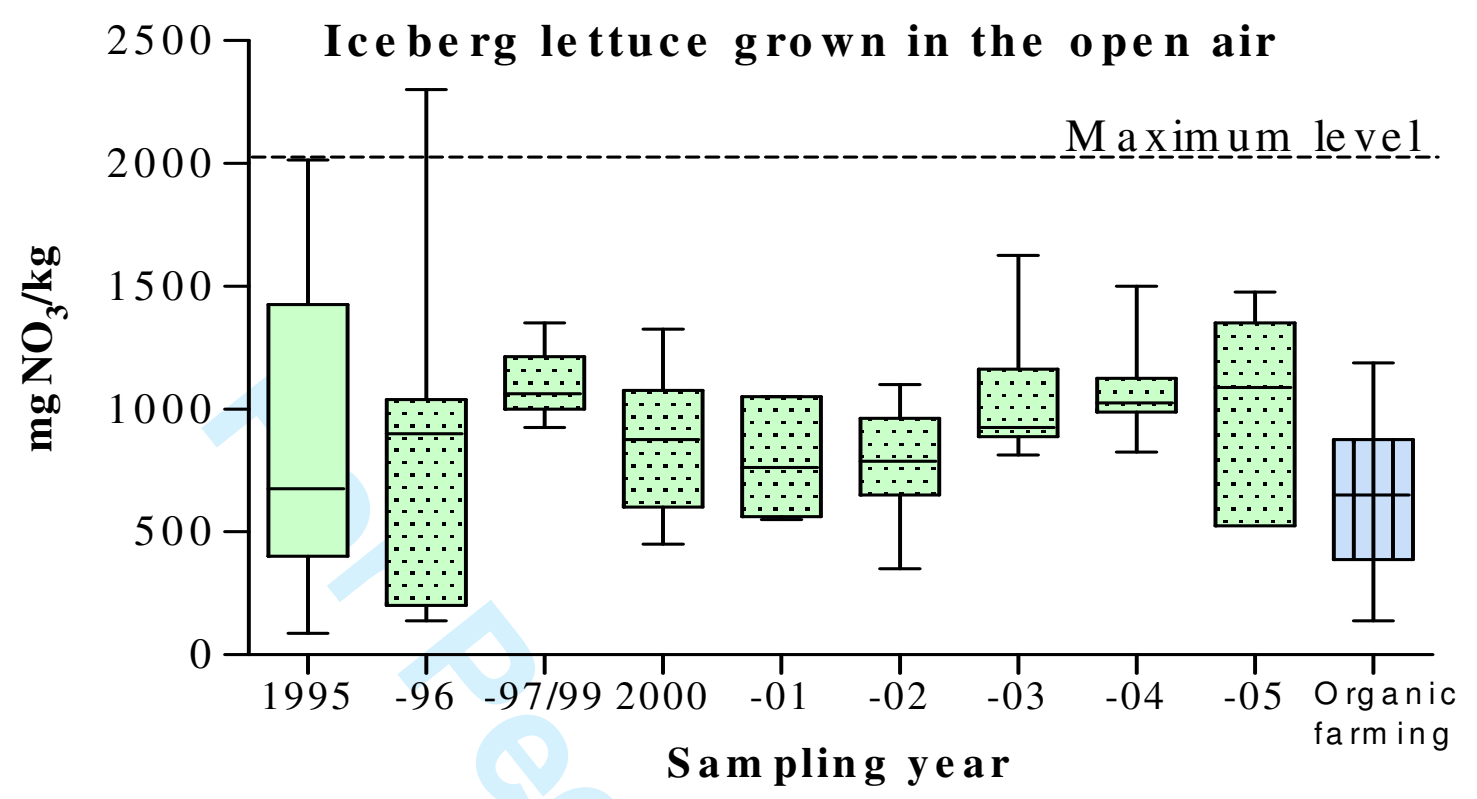

Fig. 3 


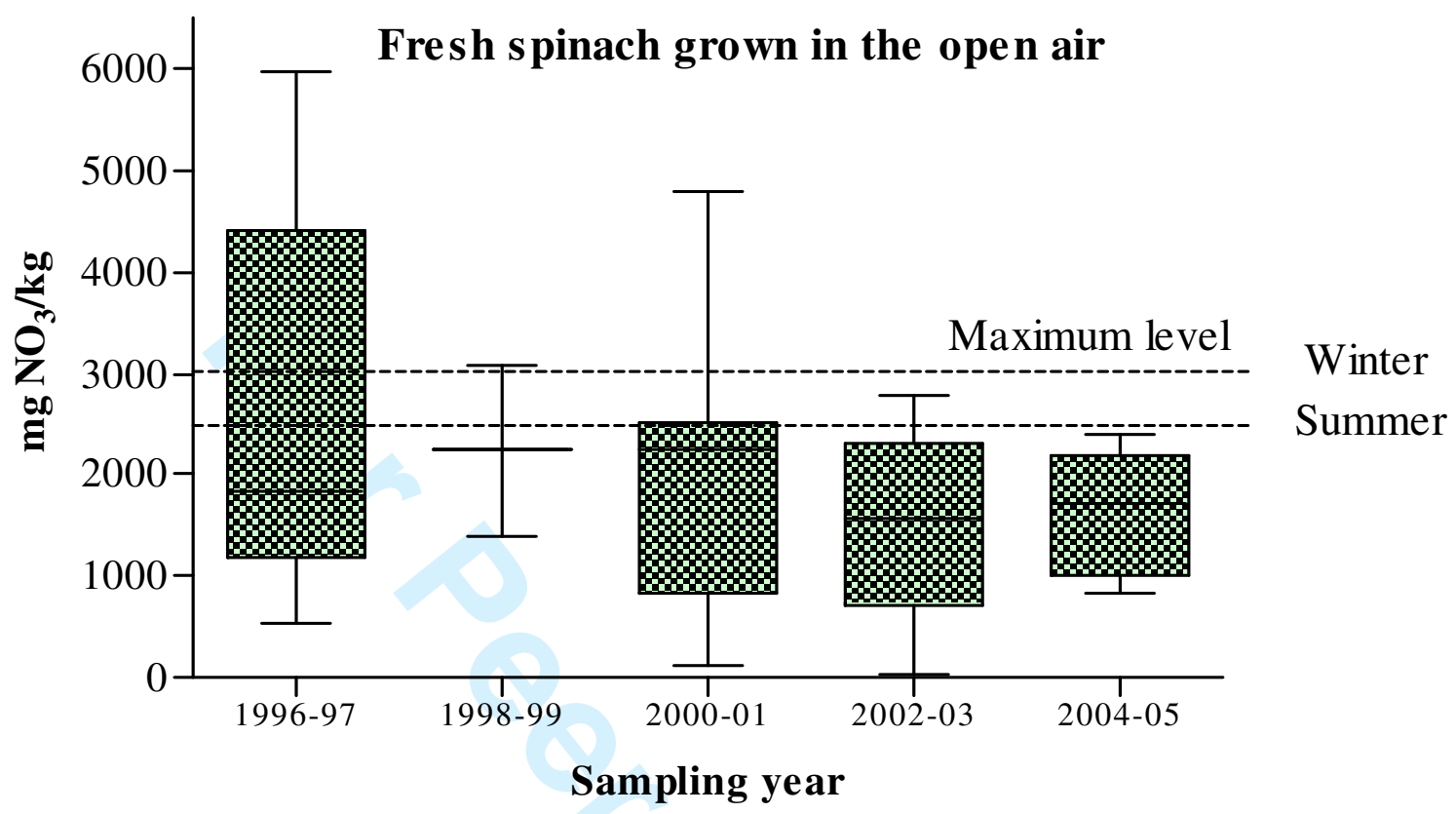

Fig 4 


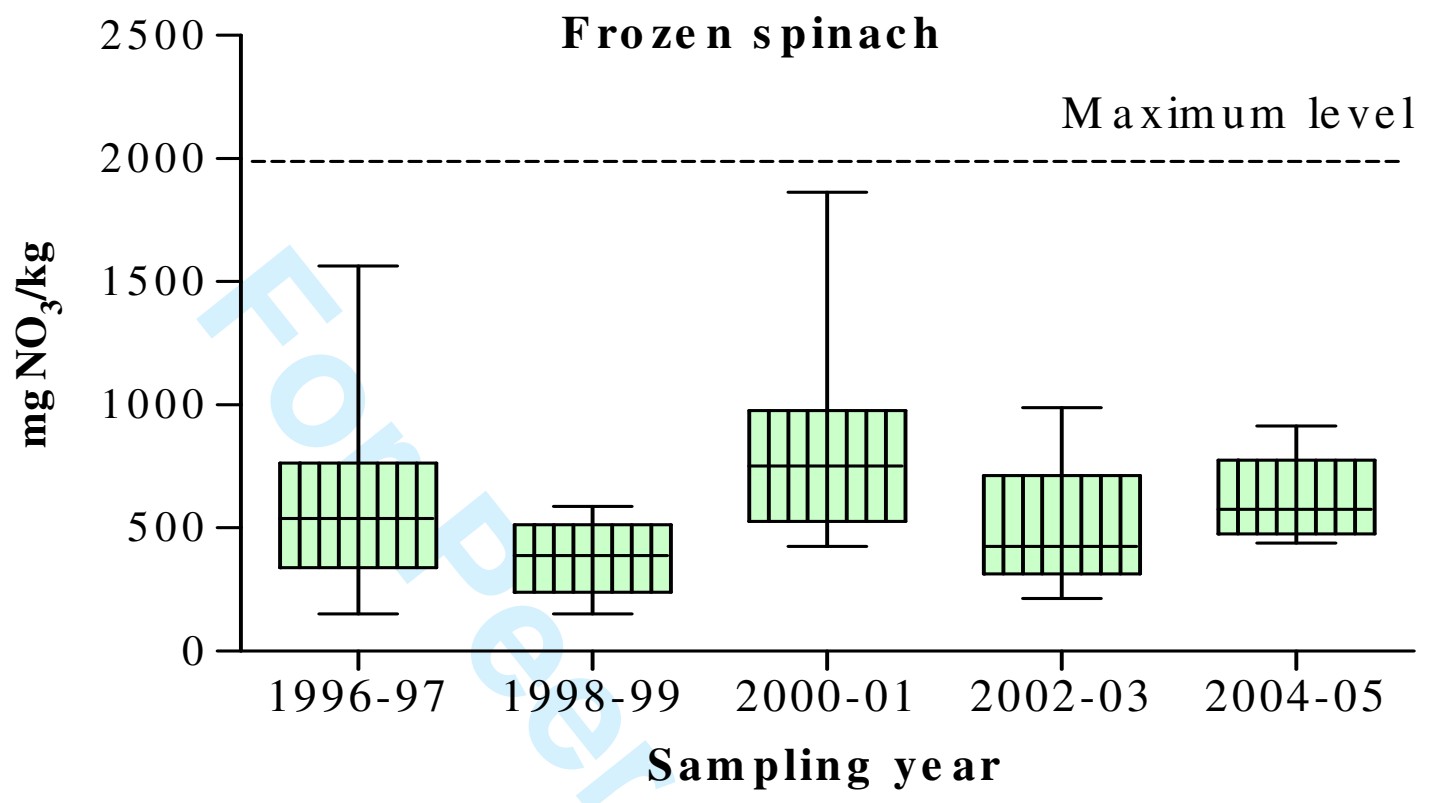

Fig. 5 